DOKTORI ÉRTEKEZÉS TÉZISEI

\title{
AZ OPPORTUNISTA HUMÁNPATOGÉN CANDIDA PARAPSILOSIS ÉLESZTÖGOMBA ELLENI TERMÉSZETES ÉS ADAPTÍV IMMUNVÁLASZ \\ VIZSGÁLATA
}

TÓTH ADÉL

TÉMAVEZETŐ:

DR. GÁCSER ATTILA

TUDOMÁNYOS FÖMUNKATÁRS

\section{BIOLÓGIA DOKTORI ISKOLA}

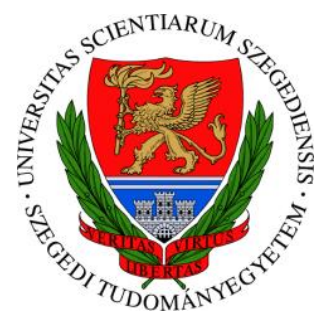

SZEGEDI TUDOMÁNYEGYETEM TERMÉSZETTUDOMÁNYI ÉS INFORMATIKAI KAR MIKROBIOLÓGIAI TANSZÉK

SZEGED

2015 


\section{Bevezetés}

Az invazív Candida fertőzés komoly egészségügyi problémát jelent napjainkban, amely főként a legyengült immunrendszerü betegeket veszélyezteti. Noha az invazív candidiasis leggyakoribb okozója a C. albicans, a nem-albicans fajok által kiváltott fertőzések előfordulási gyakorisága az utóbbi évtizedekben folyamatos növekedést mutat. A $C$. parapsilosis geográfiai régiótól függően a második vagy harmadik leggyakrabban izolált invazív candidiasist okozó faj a $C$. albicans után, jelenleg világszerte ezeknek a fertőzéseknek mintegy $17 \%$-áért felelős. Noha az utóbbi években intenzíven vizsgálják az invazív candidiasis patogenezisét, a tanulmányok túlnyomó többsége a $C$. albicans által kiváltott immunválasz kutatására irányul, míg a $C$. parapsilosis által okozott fertőzések immunológiai hátteréről jelenleg kevés ismeretünk van.

Munkánk során célunk a $C$. parapsilosis által kiváltott természetes és adaptív immunválasz néhány aspektusának jellemzése, illetve a $C$. albicans által indukált védekezési mechanizmusokkal való 
összehasonlítása volt. Vizsgáltuk a $C$. parapsilosis és a C. albicans által indukált citokin termelést és $\mathrm{T}$ helper sejt polarizációt humán perifériás vérből származó mononukleáris sejtekben, valamint egyes mintázatfelismerő receptorok, illetve intracelluláris jelátvitelben részt vevő molekulák szerepét a Candida fajok által indukált gyulladásos válasz során. Részletesen vizsgáltuk továbbá a $C$. parapsilosis és a $C$. albicans által indukált inflammaszóma aktivációt humán THP-1 makrofágokban.

\section{Alkalmazott módszerek}

Sejttenyésztés, primer sejtek izolálása

- mononukleáris sejtek (PBMC) izolálása humán perifériás vérböl

- makrofágok differenciáltatása mononukleáris sejtekből

- emlős sejtvonalak fenntartása/tenyésztése

$\underline{\text { In vitro } \mathrm{PBMC} / \text { makrofág stimuláció }}$ 
- primer sejtek és sejtvonalak in vitro stimulációja különböző Candida törzsekkel

Molekuláris technikák

- RNS izolálás

- qRT-PCR (kvantitatív valós-idejü PCR)

Immunológiai módszerek

- áramlási citometria

- intracelluláris citokin festés

- ELISA (enzimkötött immunoszorbens próba)

Egyéb módszerek

- reaktív oxigéngyök (ROS) termelés mérése

- lizoszómális katepszin B felszabadulás mérése

- laktát dehidrogenáz (LDH) aktivitás mérése 


\section{Eredmények}

1. Humán perifériás vérből izolált mononukleáris sejtek C. parapsilosis és C. albicans fertőzésre adott válaszreakciójának összehasonlítása

1.1. A C. parapsilosis és a $C$. albicans által indukált $\mathrm{T}$ helper sejt polarizáció összehasonlítása

Elöször megvizsgáltuk a hővel elölt $C$. parapsilosis és $C$. albicans által indukált gyulladásos citokin termelést humán perifériás vérből izolált mononukleáris sejtekben. Azt tapasztaltuk, hogy a $C$. parapsilosis-szal stimulált sejtek hasonló mértékü TNFa és IL-6, valamint mintegy $20 \%$-kal alacsonyabb szintü IL-1 $\beta$ termelést mutattak a C. albicans-szal fertőzött sejtekhez képest. A Th sejtes citokinek vizsgálata esetén azonban eredményeink azt mutatták, hogy a $C$. parapsilosis 48 óra elteltével szignifikánsan alacsonyabb IFN $\gamma$, ugyanakkor magasabb IL-10 termelést indukált mononukleáris sejtekben, mint a C. albicans. Továbbá, a C. parapsilosis jelentősen kisebb mértékü IL-17 és IL-22 termelést váltott ki 7 napos 
stimulációt követően. Intracelluláris citokin festést követő áramlási citometriás analízissel megerösítettük, hogy a $C$. parapsilosis-szal stimulált mintákban 7 nap elteltével alacsonyabb volt az IL-17 termelő $\mathrm{CD}^{+}{ }^{+} \mathrm{Th}$ sejtek aránya. Ezek az eredmények arra utalnak, hogy míg a $C$. albicans fertőzés Th1/Th17-domináns T-sejt polarizációt indukál, $C$. parapsilosis fertőzés esetén ez az egyensúly Th2/Treg irányba tolódik el.

1.2. A C. parapsilosis immunológiai felismerésében szerepet játszó receptorok azonosítása

A továbbiakban megvizsgáltuk a Dectin-1, TLR4 és TLR2 receptorok szerepét a $C$. parapsilosis és a $C$. albicans által indukált citokin termelésben. A Dectin-1 receptor gátlása esetén mind a $C$. parapsilosis-szal, mind a C. albicans-szal stimulált mononukleáris sejtek jelentősen csökkent citokin (TNF $\alpha$, IL-1 $\beta$, IL-6, IL-10, IFN $\gamma$ ) termelést mutattak, jelezve, hogy ez a receptor mindkét faj felismerésében fontos szerepet játszik. Ugyanakkor, míg a TLR4 blokkolása nem volt hatással a mononukleáris sejtek citokin termelésére, eredményeink 
alapján a TLR2 szerepet játszik az IL-1 $\beta$ és IL-6 indukciójában. Nem tapasztaltunk azonban jelentős különbséget a $C$. parapsilosis-szal és $C$. albicans-szal stimulált mononukleáris sejtek citokin termelésében a receptor blokkolók alkalmazása során (noha a Dectin-1 gátlása esetén a $C$. parapsilosis-szal stimulált mintákban valamivel nagyobb mértékben csökkent a TNF $\alpha$, IL-1 $\beta$, IL-6 és IL-10 szintje a C. albicans-szal fertőzött sejtekhez viszonyítva), ami arra utal, hogy egyéb receptorok aktivációja lehet felelős a két faj által indukált citokin termelés különbségéért.

1.3. A C. parapsilosis felismerését követő intracelluláris jeltovábbítás elemeinek vizsgálata

A MAPK kaszkád mind a TLR-ek, mind a CLR-ek által indított jelátvitelben szerepet játszik, az egyes MAP kinázok szerepe a szignalizáció során azonban kevésbé tisztázott. Kísérleteink során azt tapasztaltuk, hogy mind a három klasszikus MAP kináz (p38, ERK, JNK) gátlása jelentősen csökkentette mind a $C$. parapsilosis-szal, mind a $C$. albicans-szal stimulált mononukleáris sejtek citokin 
(TNF $\alpha$, IL-1 $\beta$, IL-6, IL-10, IFN $\gamma$ ) termelését, jelezve, hogy mindhárom enzim szerepet játszik a két Candida faj felismerését követő jelátvitelben. Továbbá, míg a p38 és ERK inhibíció a $C$. parapsilosis-szal stimulált minták citokin (TNFo, IL-1 $\beta$, IL-6) termelését csökkentette nagyobb mértékben, a JNK gátlása a $C$. albicans-szal stimulált minták citokin szekréciójára volt nagyobb hatással. Ezek az eredmények arra utalnak, hogy az egyes MAP kinázok citokin indukcióban betöltött szerepe különbözik $C$. parapsilosis és $C$. albicans stimuláció esetén.

2. A C. parapsilosis és a $C$. albicans által indukált inflammaszóma aktiváció összehasonlítása

A mononukleáris sejtek élő $C$. parapsilosis-szal és $C$. albicans-szal történő stimulációja során azt tapasztaltuk, hogy míg mindkét faj azonos mértékben indukálta a TNFa és IL-6 termelést, a $C$. parapsilosis jelentősen alacsonyabb IL-1 $\beta$ szekréciót váltott ki, mint a $C$. albicans. A továbbiakban ennek a különbségnek a hátterében meghúzódó lehetséges mechanizmusokat 
vizsgáltuk részletesen. Az IL-1 $\beta$ érett formájának kialakulása monocitákban és makrofágokban kaszpáz-1-, illetve inflammaszóma-aktiváció-függő. Míg monocitákban a kaszpáz-1 folyamatosan aktív, makrofágokban elöször a pro-kaszpáz-1 hasítása szükséges az enzim aktivációjához. Kísérleteink során PMA-kezelt THP-1 makrofágokban vizsgáltuk a $C$. parapsilosis és a $C$. albicans által indukált inflammaszóma aktivációt. Azt tapasztaltuk, hogy a $C$. parapsilosis csak hosszú inkubáció után és viszonylag nagy sejtszám esetén indukálta az IL-1 $\beta$ szekréciót, ellentétben a $C$. albicans-szal, amely már néhány óra elteltével jelentős IL-1 $\beta$ termelést váltott ki. Noha $C$. albicans esetén a hifaképzésnek fontos szerepet tulajdonítanak az inflammaszóma aktiváció során, érdekes módon eredményeink szerint az IL-1 $\beta$ szekréció mértéke független volt a $C$. parapsilosis pszeudohifák jelenlététől. Továbbá, nem tapasztaltunk különbséget a THP-1 makrofágokban az IL-1 $\beta$ mRNS és pro-IL-1 $\beta$ szintjében $C$. parapsilosis és $C$. albicans stimulációt követően, ami arra utal, hogy a csökkent IL-1 $\beta$ szekréció nem transzkripciós vagy transzlációs különbségek 
eredménye, hanem a pro-IL-1 $\beta$ alacsony hatékonyságú aktivációjából adódik. Különböző inhibitorok alkalmazása segítségével kimutattuk, hogy mind a $C$. parapsilosis-szal, mind a C. albicans-szal stimulált THP1 sejtekben hasonló módon képződik az érett IL-1 $\beta$, és a folyamat kaszpáz-1-, kaszpáz-8-, Syk- és TLR4-függő. Az NLRP3 és ASC deficiens THP-1 sejtekkel folytatott kísérletek megerősítették, hogy az IL-1ß szekréció mindkét faj esetén NLRP3 inflammaszóma aktivációfüggő. Az NLRP3 inflammaszóma aktivációjában szerepet játszó három legfontosabb mechanizmus a reaktív oxigéngyökök képződése, a katepszin $B$ lizoszómából történő felszabadulása, illetve az intracelluláris $\quad \mathrm{K}^{+} \quad$ koncentráció csökkenése. Eredményeink szerint az IL-1 $\beta$ szekréció mind $C$. parapsilosis, mind C. albicans stimulációt követően $\mathrm{K}^{+}$efflux függőnek bizonyult, a katepszin $\mathrm{B}$ gátlása azonban nem volt hatással a THP-1 sejtek IL- $1 \beta$ termelésére, noha a $C$. albicans intenzívebb katepszin B felszabadulást indukált, mint a $C$. parapsilosis. Továbbá, a NADPHoxidáz gátlása jelentősen csökkentette mind az intracelluláris pro-IL-1 $\beta$, mind a szekretált IL-1 $\beta$ szintjét, 
jelezve a ROS lehetséges szerepét az inflammaszóma aktivációban. Ezt erősíti az az eredményünk is, miszerint a $C$. albicans intenzív ROS termelést indukált THP-1 makrofágokban, míg a $C$. parapsilosis a fertőzés első négy órájában egyáltalán nem indukálta a reaktív oxigéngyökök képződését. Ezen túlmenően kimutattuk, hogy az inflammaszóma aktiváció $C$. albicans fertőzés esetén fagocitózis-függő, és a THP-1 sejtek szignifikánsan nagyobb mértékben fagocitálják a $C$. albicans, mint a $C$. parapsilosis sejtjeit. Eredményeink alapján úgy tünik, hogy számos mechanizmus közrejátszik abban, hogy a $C$. parapsilosis alacsonyabb szintű IL-1 $\beta$ szekréciót indukál, mint a $C$. albicans. 


\section{Összefoglalás}

Kísérleteink során kimutattuk, hogy:

1. A $C$. parapsilosis a $C$. albicans-hoz hasonló mértékben indukálja a TNF $\alpha$ és IL-6, azonban szignifikánsan kisebb mértékben az IL-1 $\beta$ termelését mononukleáris sejtekben

2. Míg a $C$. albicans Th1/Th17 irányú polarizációt indukál mononukleáris sejtekben, C. parapsilosis fertőzés esetén az egyensúly Th2/Treg irányba tolódik el

3. A Dectin-1 receptor fontos szerepet játszik mind a $C$. albicans, mind a $C$. parapsilosis immunológiai felismerésében

4. A p38, ERK és JNK MAP kinázok fontos szerepet játszanak a $C$. parapsilosis és $C$. albicans által indukált citokin termelés indukciójában, az egyes kinázok szerepe azonban kismértékben különbözik $C$. parapsilosis és $C$. albicans fertőzés esetén

5. A C. parapsilosis szignifikánsan kisebb mértékü IL$1 \beta$ szekréciót indukál THP-1 makrofágokban, mint a 
C. albicans, ami a pro-IL-1 $\beta$ alacsony hatékonyságú hasításából adódik

6. A C. parapsilosis által indukált IL-1 $\beta$ termelés THP1 makrofágokban kaszpáz-1, kaszpáz-8, Syk, TLR4, ASC és NLRP3-függő

7. A C. parapsilosis által kiváltott IL-1ß szekréció független a pszeudohifák jelenlététől

8. A C. albicans szignifikánsan nagyobb mértékü ROS termelést és katepszin B felszabadulást indukál THP1 makrofágokban, mint a $C$. parapsilosis

9. A C. parapsilosis és $C$. albicans által indukált IL-1 $\beta$ termelés $\mathrm{K}^{+}$efflux és NADPH-oxidáz-függő, azonban független a katepszin B aktivitásától

10. A THP-1 makrofágok szignifikánsan nagyobb mértékben fagocitálják a $C$. albicans, mint a $C$. parapsilosis sejtjeit 


\section{Referált folyóiratban megjelent közlemények}

Toth, A, Csonka, K, Jacobs, C, Vagvolgyi, C, Nosanchuk, J D, Netea, M G, Gacser, A (2013). "Candida albicans and Candida parapsilosis induce different T-cell responses in human peripheral blood mononuclear cells." J Infect Dis 208(4): 690-698. IF: 5,778

Nemeth, T, Toth, A, Hamari, Z, Falus, A, Eder, K, Vagvolgyi, C, Guimaraes, A J, Nosanchuk, J D, Gacser, A (2014). "Transcriptome profile of the murine macrophage cell response to Candida parapsilosis." Fungal Genet Biol 65: 48-56. IF: 3,262

Toth, A, Nemeth, T, Csonka, K, Horvath, P, Vagvolgyi, C, Vizler, C, Nosanchuk, J D, Gacser, A (2014). "Secreted Candida parapsilosis lipase modulates the immune response of primary human macrophages." Virulence 5(4): 555-562. IF: 3,319

Grozer, Z, Toth, A, Toth, R, Kecskemeti, A, Vagvolgyi, C, Nosanchuk, J D, Szekeres, A, Gacser, A (2015). "Candida parapsilosis produces prostaglandins from exogenous arachidonic acid and OLE2 is not required for their synthesis." Virulence 6(1): 85-92. IF: 3,319

Nemeth, T, Toth, A, Szenzenstein, J, Horvath, P, Nosanchuk, J D, Grozer, Z, Toth, R, Papp, C, Hamari, Z, Vagvolgyi, C, Gacser, A (2013). "Characterization of Virulence Properties in the C. parapsilosis Sensu Lato Species." PLoS One 8(7): e68704. IF: 3,534

Pallagi, P, Balla, Z, Singh, A K, Dosa, S, Ivanyi, B, Kukor, Z, Toth, A, Riederer, B, Liu, Y, Engelhardt, R, 
Jarmay, K, Szabo, A, Janovszky, A, Perides, G, Venglovecz, V, Maleth, J, Wittmann, T, Takacs, T, Gray, M A, Gacser, A, Hegyi, P, Seidler, U, Rakonczay, Z, Jr. (2014). "The role of pancreatic ductal secretion in protection against acute pancreatitis in mice*." Crit Care Med 42(3): e177-188. IF: 6,147

Toth, R, Toth, A, Papp, C, Jankovics, F, Vagvolgyi, C, Alonso, M F, Bain, J M, Erwig, L P, Gacser, A (2014b). "Kinetic studies of Candida parapsilosis phagocytosis by macrophages and detection of intracellular survival mechanisms." Front Microbiol 5: 633. IF: 3,941

Tako, M, Toth, A, L, G N, Krisch, J, Vagvolgyi, C, Papp, T (2010). "A new beta-glucosidase gene from the zygomycete fungus Rhizomucor miehei." Antonie Van Leeuwenhoek 97(1): 1-10. IF: 1,673

\section{Összesített impakt faktor: 30,973}




\section{Társszerzői nyilatkozat}

Kijelentem, hogy Tóth Adél szerepe meghatározó jelentőségü volt a

Toth, A, Csonka, K, Jacobs, C, Vagvolgyi, C, Nosanchuk, J D, Netea, M G, Gacser, A* (2013). "Candida albicans and Candida parapsilosis induce different Tcell responses in human peripheral blood mononuclear cells." J Infect Dis 208(4): 690-698. IF: 5,778

Nemeth, T, Toth, A, Hamari, Z, Falus, A, Eder, K, Vagvolgyi, C, Guimaraes, A J, Nosanchuk, J D, Gacser, A* (2014). "Transcriptome profile of the murine macrophage cell response to Candida parapsilosis." Fungal Genet Biol 65: 48-56. IF: 3,262

címmel megjelent közleményekben, így az értekezésben és a publikációkban közölt eredményeket tudományos fokozat (Ph.D.) megszerzésére nem használtuk fel és ezt a jövőben sem fogjuk tenni.

*felelős szerző

Dr. Gácser Attila 